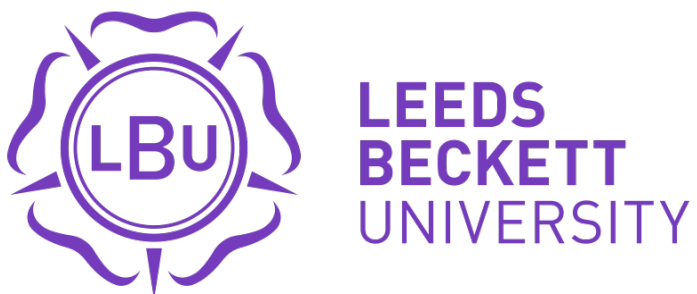

Citation:

Joseph-Salisbury, R (2018) Black mixed-race men, perceptions of the family, and the cultivation of 'post-racial' resilience. Ethnicities, 18 (1). pp. 86-105. ISSN 1468-7968 DOI: https://doi.org/10.1177/1468796817739667

Link to Leeds Beckett Repository record:

https://eprints.leedsbeckett.ac.uk/id/eprint/4400/

Document Version:

Article (Accepted Version)

The aim of the Leeds Beckett Repository is to provide open access to our research, as required by funder policies and permitted by publishers and copyright law.

The Leeds Beckett repository holds a wide range of publications, each of which has been checked for copyright and the relevant embargo period has been applied by the Research Services team.

We operate on a standard take-down policy. If you are the author or publisher of an output and you would like it removed from the repository, please contact us and we will investigate on a case-by-case basis.

Each thesis in the repository has been cleared where necessary by the author for third party copyright. If you would like a thesis to be removed from the repository or believe there is an issue with copyright, please contact us on openaccess@leedsbeckett.ac.uk and we will investigate on a case-by-case basis. 


\title{
Black Mixed-Race Men, Perceptions of the family, and the Cultivation of Post-Racial Resilience
}

\author{
Abstract \\ Historically and contemporarily, popular discourses have pathologised Black mixed-race men \\ as the embodiment of a 'clash of cultures'. In centring the voices of Black mixed-race men in \\ the UK and the US, this article offers a refutation to these discourses.
}

With a specific focus on secondary schooling, the article draws upon accounts from semistructured interviews in order to demonstrate how Black mixed-race men perceive their families to offer a source of strength and support. In order to understand how the family supports Black mixed-race men in overcoming the challenges posed by a hostile, 'post-racial' white supremacist environment, I develop a conceptualisation of 'post-racial' resilience. Through this concept, I highlight the creative and innovative ways Black mixed-race men and their families respond to the lived realities of pervasive racial inequities that are occluded by 'post-racialism'. The article considers the role that parents play in three inextricably linked aspects of Black mixed-race men's lives: schooling, identity formation, and experiences of racism.

Keywords: post-racial resilience; Black mixed-race men; family; parents; school 


\section{Introduction}

Historically the Black family has been seen to reproduce and perpetuate deviance and pathology (Gilroy 1993), manifest conflict between parent and child (Hines and BoydFranklin 2005, Staples 1999), and constructed as 'mutilated and dysfunctional' (Alexander 1996: 65). Simultaneously, the mixed-race family, and particularly the Black mixed-race family, manifests as a social taboo (Twine, 2010), and is depicted as being 'fraught with difficulty' (Reddy 1996, Song 2015). The belief in the problematic nature of a 'clash of cultures' has pathologised these families and their children. This has led to a belief that Black mixed-race children come from broken homes, and that this can have implications for their wellbeing and schooling (Tikly et al., 2004, Tizard and Phoenix 2002). There are a disproportionate number of Black mixed-race children in the care system (Boushel 1996) and a widespread but unsubstantiated perception in of 'high levels of failure in interracial relationships' (Ali 2003: 7). As recently as 2006, the then chairman of the commission for racial equality, Trevor Phillips, spoke of 'children who grow up marooned between two communities' (Tate 2015: 188). It has been observed that this discourse of pathology permeates the school environment and shapes the perceptions of teachers (Author A, 2016, Tutwiler 2016, Williams 2011).

The school is an institution underpinned by systemic white supremacy (Gillborn 2008). As such, the school presents a range of barriers to the schooling of racially minoritised students generally, and Black mixed-race men particularly (Author A, 2016, Author A and co-author, 2016; Williams 2011). Moreover, schools pose a potential threat to the lived experiences and positive identity formation of Black mixed-race men (Tikly et al., 2004). Such structural issues offer an explanatory insight into the low attainment levels and high exclusion rates of Black mixed-race men that move beyond fallacious cultural deficit explanations. 
This article demonstrates how Black mixed-race men perceive their families to take on myriad and diverse approaches to schooling, identity formation, and experiences of racism. In so doing, the article seeks to add to the growing body of research that has debunked the aforementioned mythical racialised and racist view of the families of Black mixed-race men (Song 2015). As will be argued, Black mixed-race families are potential sites for the cultivation of creative and innovative strategies that aid the 'post-racial' resilience of Black mixed-race men.

Despite the growth of Critical Mixed Race Studies (CMRS), the literature on mixed-race populations remains relatively underdeveloped (Daniel et al., 2014). Of the research that has been carried out, with few exceptions (Author A, 2016; Author A and co-author, 2016), research specifically focusing on Black mixed-race men is a notable absence. This is perhaps unsurprising given that the 'Mixed Race Movement' that arose in the 1990s has been critiqued for being primarily concerned with mixed-race women (Christian, 2000; McNeil, 2010; Small, 2001)

Similarly, despite research highlighting how families develop strategies to deal with racism (Ward, 1996), research exploring the role that families can play in the lives of their mixedrace children is relatively limited. Much of the early scholarship is now outdated, social-work orientated, and/or based upon clinical samples (Banks, 1995; 1996; Boushel, 1996; Maximé, 1993; Owusu-Bempah, J. 1994). While most contemporary CMRS research has focused on Black/white mixedness (perhaps neglecting other mixed-race groups), it has mostly focused on either individuals or their parents with few studies drawing the two experiences together. A notable exception is Bauer's (2010) ethnographic study of mixed race families in London. With that study focusing on the period between 1953 and 2003, the current study - situated in a post-racial context - might be seen to build upon that work. In the context of the current 
article, two other studies that deserve more than a passing mention are Rockquemore and Laszloffy's (2005) work on parenting Black/white 'biracial' children, and Frances Winddance Twine's research $(2004 ; 2010)$ on white mothers of Black mixed-race children.

Rockquemore and Laszloffy's (2005) work highlights how racial socialisation takes on particular forms in mixed-race families. The authors argue that the absence of a substantive mixed-race community, and the likelihood that Black mixed-race children are raised by monoracial parents who have different experiences of racialisation, combine to 'complicate' the experiences of Black mixed-race families (2005: 61). The authors argue that Black parents necessarily engage in the 'active racial socialisation' that fosters 'the development of skills and strategies for negotiating the pressures of living within a racially oppressive environment'. Whilst the 'invisibility of whiteness' (2005: 67) means this often is not the case in white families, due to their exposure to what Dalmage (2000) has called 'rebound racism', white parents can develop the racial consciousness required to actively racially socialise Black mixed-race children. It is this, in particular, that Frances Winddance Twine really develops.

Highlighting the ways in which white mothers of Black mixed-race children develop racial consciousness, Twine's work $(2004 ; 2010)$ offers an important and timely corrective to the longstanding stereotypes of 'broken homes' and irreconcilable 'culture clashes'. According to Twine (2010: 106) white mothers can cultivate a sense of 'double vision' as they learn to see the world through the eyes of their children (Murad, 2005; Wilson, 1989). Whilst epistemologies of ignorance mean that many white people do not see racism (Mills, 2007), Twine (2010) shows that for white women who are members of Black mixed-race families, racism can become an undeniable fact of life. The development of what Twine (2010) calls racial literacy enables white mothers to understand how racism shapes society generally, and 
their children's lives particularly. Thus, white mothers come to realise that 'their children would encounter racism and they needed resources to defend themselves against it' (Twine, 2010: 140).

This article develops upon the two works mentioned here in at least four ways. Firstly, as with so much of the existing literature, Twine (2010) observes that her centring of white parents offers 'a partial and restricted view of the dynamics in these families'. Similarly, Rockquemore and Laszloffy (2005) tend to focus on the parents, particularly on their identity and psychosocial development. By focusing on Black mixed-race men and how they draw upon the family 'resources' as a source of support, I shift the focus.

Secondly, the focus on men signals an important and long overdue interrogation of the way gender intersects with Black mixed-race identities. This is important as, despite widespread recognition of the way race and gender intersect to create differentiated experiences generally, and differentiated educational outcomes particularly, CMRS has been slow to consider how gender intersects with mixedness. Educational data in the UK shows the attainment of Black mixed-race men to be considerably lower than that of their female counterparts. The aforementioned work from Rockquemore and Laszloffy (2005) does give some consideration to the intersection of gender, but focuses closely on the challenges faced by Black mixed-race girls. Thus, the focus of this article should be a welcome addition to the field.

Thirdly, by focusing on the UK and the US, I begin to show how - despite the countries' different historical positions - many of the challenges that Black mixed-race families face and the forms of resistance they develop - transcend the Atlantic. Fourthly, given that both those pieces of research focus on a time period earlier than mine, I am also particularly 
interested in what the 'post-racial' turn means for the cultivation of these resources. I argue that Black mixed-race men convert family support - including the racial literacy of parents (Twine, 2010) - into what I call post-racial resilience.

\section{Post-Racial Resilience}

To understand post-racial resilience, it is necessary first to understand what is invoked by the 'post-racial' turn. The 'post-racial' turn describes the transition into an epoch in which, particularly among whites, race is no longer believed to be a determinant of life chances (Wise, 2013). In a large part, this is precipitated and perpetuated by what 'post-racialists' take to be the ultimate symbol of racism's demise: the election of a Black mixed-race man to the presidency of the United States (Howard and Flennaugh, 2011). However, whilst racism is widely regarded as a thing of the past, 'the enduring conditions made and marked by the racial continue to structure society. This is so regardless of the fact that its various explicit manifestations may now be rejected, rendered implicit, silenced or denied' (Goldberg, 2015: 6). In the apparent absence of racism, 'post-racialism' lends itself to cultural deficit explanations. Under these conditions Black mixed-race male 'underachievement' is not seen as a consequence of structural racism, but as a consequence of the individual failures of Black mixed-race men and/or their culture and communities. Let us now consider resilience generally, and post-racial resilience specifically.

According to Hall and Lamont (2013: 14) social resilience describes the creative processes 'in which people assemble a variety of tools, including collective resources and new images of themselves, to sustain their well-being'. Extending this definition, the current article argues that in the context of schooling, resilience is not only about the sustainment of 'wellbeing', although this is important, but also about sustaining school attainment. Indeed, respondents felt, as has been suggested elsewhere (Tikly et al. 2004), that well-being, positive 
identity formation, and school success were interactional factors. The current article identifies systemic white supremacy - as it operates at all levels of the lives of Black mixed-race men to be the meta-threat against which Black mixed-race men must be resilient. In the context of schooling therefore, resilience can be understood as the ability to resist the racial disadvantage that a white supremacist schooling system presents (Clennon 2014). Of course the need to be resilient is nothing new to racial minorities, however, in 'post-racial' times this is a threat that is obfuscated. Thus, Black mixed-race men must remain resilient against a threat that is denied and invisibilised (Goldberg 2015). It is in this sense then that post-racial resilience is characteristically different from the forms of resilience that characterise Black experiences of the past.

According to Morley and Street (2014: 27) 'the development of resilience is important and can happen as the result of being well supported through difficult times'. As has been shown to be the case in other studies of racially minoritised men in schooling (Byfield, 2008; Rhamie, 2007), for the Black mixed-race men in the current study, pervasive racism ensured that the threat of racism was ubiquitous. The support of Black mixed-race men's families constitutes a protective factor in the development and maintenance of Black mixed-race men's 'post-racial' resilience (Jackson et al., 2013). In her research on the experiences of Black learners in Britain, Rhamie (2007: 15) reflects on what she sees as the important role of the family,

Successful children are those who learn to navigate through these negatives and minimise their impact. They are able to do so because they come from strong, supportive homes. 
Whilst it might be more appropriate to speak of those racially minoritised students that are failed by the school system as oppose to 'unsuccessful children' (Gillborn 2001), the fundamental point is evident in research elsewhere (Byfield 2008), and is in keeping with the argument of the current article. That is, Black mixed-race men's families are a site for the cultivation and maintenance of the post-racial resilience required to navigate white supremacist terrain. For DeVerteuil (2015: 8), conceptually, 'resilience shifts attention from risk and vulnerability to something more positive and prospective on analysing the capacity of people... to anticipate, persist with, adapt and minimise the damage caused by change, risk and adversity'. In this sense the concept is useful in the pursuit of Critical Race Theory (CRT) aims of challenging pathological accounts of racially minoritised groups (Hylton 2012). Although somewhat interlinked, for the sake of this article, the role of the family in the resilience maintenance of Black mixed-race men can be split into three components; parents on schooling; parents on identity; and, parents on racism. In the discussion that follows the methods section, I discuss each of these in turn as I demonstrate how the families of Black mixed-race men cultivate post-racial resilience.

\section{Methods}

This article draws upon data collected as part of a research project which - with a particular focus on secondary schools - explores the way in which Black mixed-race men in the UK and US constitute their identities.. The UK and the US make interesting sites for considering the identity constitution and lived experiences of Black mixed-race men (Gilroy, 1993). Given their interlinked migratory histories (Morning, 2012), both countries have a shared history of the Black-white racial dichotomy and of viewing mixedness 'as an illegitimate state outside the either/or binary' (Caballero, 2004: 12). These two countries are still shaped by the residual impact of transatlantic slavery and the imposition of white superiority and Black 
inferiority (Caballero, 2004); white supremacy is at the core of the structure of each country, and this characterises schooling (Gillborn and Ladson-Billings 2004)

The relationality between the two contexts is evident in the parallels between two early sociological works on mixedness; the Fletcher report in the UK (Fletcher, 1930) and marginal man thesis in the US (Stonequist, 1937); both of which posit that the mixed-race population are marginal and pathological. Scholars like Platt (2012) have since observed the crosspollination of analysis with perhaps a UK reliance on US literature. Although somewhat different in nature, the parallels between the US's 2000 and UK's 2001 inclusion of mixedrace options on their respective national censuses also hints at a Transatlanticity of mixedness. Finally, research from Warikoo (2011) who looks at youth culture in UK and US schools finds remarkable similarities between the two contexts.

The project was influenced by Critical Race Theory (CRT) approaches that seek to counter dominant white-centric narratives (Hylton 2012). With this in mind, the researcher interviewed fourteen Black mixed-race men who had been to school in the UK, and fourteen Black mixed-race men who had been to school in the US. Whilst this is a relatively small sample, it does give us an insight into the lived experiences of these Black mixed-race men and their families. Just as future research might draw upon, and hopefully build upon this project, the analysis here is strengthened as it is situated alongside existing research. On average, interviews lasted between 45 minutes and an hour and were conducted between October 2014 and May 2015. The project adopted a largely purposive theoretical approach. This allowed for the adherence to the fundamental aim of centralising race (Malagon, Huber and Velez 2009). 
Each of the men were aged between sixteen and twenty-one at the time of the semi-structured interview and were recruited through poster advertisement on social media, and more latterly, through word-of-mouth and snowballing. The advertisements used a range of different terminologies including 'black/white mixed-race', 'of mixed black and white parentage' and 'black/white biracial'. Given the range of ways in which this population express their racial identities (Aspinall 2003) this was deemed necessary in order to recruit a diverse sample.

The discussions with interviewees were largely open ended but focused primarily on their experiences of secondary schooling. These discussions opened out into much broader conversations about the men's lived experiences, particularly in relation to the race and gender identities. The interviews covered a number of subthemes. One recurrent theme, largely led by the interviewees themselves, was that of the role of the family generally, and the role of parents particularly. It is this aspect of the interviews that this article discusses.

\section{Discussion}

\section{Parents on Schooling of Black Mixed-Race Men}

Despite a plethora of research highlighting the educational desire of Black communities (Andrews 2013, hooks 2004, Mirza and Reay 2000) on both sides of the Atlantic the dominant discourse on the Black family has been one that has depicted educational disinterest (Andrews, 2013; Warmington, 2014). This is a discourse that has readily been applied to the families of Black mixed-race men. As the 'post-racial' occludes the possibility for structural critiques, a lack of Black educational desire is offered as an explanation for the low attainment of Black mixed-race men (Tikly et al. 2004, Williams 2011). However, for the Black mixed-race men in this study, the educational desire of the family was regarded as a fundamental component in their post-racial resilience. This is apparent in the following account from Reggie (US) as he discusses his high school attainment, 
I attest it to my parents because they instilled it in me from a young age to like, you know what I mean, get on your studies. Don't do this; don't do that.

Reggie's account here is representative of several in the study. Not only does he demonstrate the important role that parents can play in the schooling of their Black mixed-race sons, but he simultaneously disrupts the pathological discourses that imbricate Black mixed-race men's families. In many cases, educational desire and high expectations came alongside an eschewing of the logic of 'post-racialism'. Reece (UK) demonstrates this point,

My Mum and Dad were like you need to do well at school. The big focus there is that they're so aware of the fact that Black and mixed-race kids that tend not to do so well at school tend to fill their time with other things... my Mum was kind of explaining to me the idea of not being another statistic in terms of kind of like saying 'this age range of Black men are unemployed' she said Black, you know? Because in that instance she knows that outside there isn't a great deal of difference between you being mixed-race and you being Black.

Reece's account here demonstrates that the influence of parents in the cultivation of their son's 'post-racial' resilience was not abstractly about doing well in school, but about doing well in a school and society underpinned by white supremacy in which Black mixed-race men are at a disadvantage, and not expected to 'succeed' (Andrews 2013). Reece's father is Black and his mother is white: notice that it is his mother who Reece recalls recognizing the significance of race (Twine, 2010). Reece's mother rejects 'post-racial' logic and pre-empts her son's racial interpellation as a pathological Black man. Thus, in preparing him accordingly, she seeks to cultivate the 'post-racial' resilience that will enable him to resist becoming that pathological Black man; 'another statistic'. Whilst 'post-racial' logic depicts 
schooling as meritocratic and free from the constraints of racial inequity, Reece's Mum rejects this mythology. In so doing, she demonstrates what Twine (2010) describes as racial literacy. It is noteworthy that this racial literacy recognises the intersection of gender. Reece notes how his mother recognises the processes of identity erasure that Black mixed-race men face as they are interpellated as part of the pathological Black same of the white imaginary (Tate, 2005; Yancy, 2008). This is the process we see as, after being shot dead by police, Mark Duggan was 'uniformly referred to as a 'black man' in the media' (Beckles-Raymond, 2016: 73). To be clear, the advice of Reece's mother was not just about race, but about the particular challenges that Reece faces at the intersection of race and gender. As with so much of Black mixed-race men's experiences, the notion of 'not being a statistic' appeared to transcend the Atlantic. Will (US) recalled his white mother telling him,

you're not a number and you're gonna go to arts school, so when you get to arts school you can prove you're not a number'. And once I'd proved that I'm not a number and got into a really awesome school, I was like 'Oh shit. Like, I'm not a number.

The first important move is for Will's mother to recognise the racial inequalities that pervade society generally, and schooling particularly. As this is something that is transmitted to Will, it becomes an important element in his 'post-racial' resilience: he is better able to identify the threats he faces. The second move from Will's mother is to invert the racism that threatens to disadvantage her son, and use it as a source of motivation. This is what we see as - bolstered by his mother's guidance - Will's 'post-racial' resilience enables him to get 'into a really awesome school' and speak back to the pressures that threaten to reduce Black mixed-race men to 'a number'. What begins to develop here is a picture of Black mixed-race men and 
their families that moves beyond the pathological representations of agency-less victims and shows the family as a site of racial literacy, agency and resilience.

In both the accounts of Will (US) and Shaun (UK) we see that the high expectations of parents and the family act to strengthen the men's 'post-racial' resilience in the face of the low expectations that permeate society generally, and the school particularly (Author A, 2016). Of course, under 'post-racial' conditions, these low expectations are always denied. These accounts also support Twine's (2010) findings that white parents can and do often develop the racial literacy necessary to support their Black mixed-race sons. The influence of parents was not always confined to interaction with their sons. Where necessary many parents showed a willingness to engage and challenge the school. This is evident in Jamal's (UK) account,

There was only one incident with a teacher, when they gave me a poor grade for a good piece of work, my mum complained at parent's evening that the teacher had prior expectations of what I could achieve and marked me accordingly. My grade was subsequently bumped up.

As in the accounts of Will and Shaun, Jamal's white mother demonstrates that, despite the logic of 'post-racialism' gaining hegemony, she is racially literate. Who lives it, knows it, so goes the adage, and parents can come to live and know through their sons (Wilson, 1987). Whilst 'post-racialism' might encourage us to see Jamal's low grade as a consequence of his individual failure - or the failure of his family, community and culture - Jamal's mother remains aware of the way that racism permeates her son's experiences of schooling. As Rhamie and Hallam (2002) argue, decades of inequality in schooling have engendered a necessary level of distrust among parents and communities of racially minoritised students. 
This distrust becomes an important element of parental racial literacy and, through the direct intervention of Jamal's mother, we see how this bolsters Jamal's 'post-racial' resilience. Parents of Black mixed-race sons challenging the school was a recurrent theme among UK and US participants. Participants recalled their parents challenging schools on a multitude of issues from educational streaming and curricular erasure, to racialised, and perhaps gendered, pressures to pursue sporting rather than academic activities.

The value placed upon schooling, and the contiguous high expectations of parents, underpinned by an awareness of systemic white supremacy, constitute a key contributing factor to the cultivation of Black mixed-race men's 'post-racial' resilience. Alongside schooling, parents played an important role in their sons' identity formation.

\section{Parents on the Identity of Black Mixed-Race Men}

Sanders (1997) and others have argued that parents' ability to facilitate the development of positive racial identities can be a determinant factor in the school success of their children (Yan 1999). This can be seen as a resilience enhancing factor (Miller 1999, Miller and MacIntosh 1999) against the threat of poor self-esteem (Morley and Street 2014), and is an essential element of racially minoritised parenting (Collins 1994). As Greene (1990: 218) notes, parenting of racially minoritised students involves tasks that are not incumbent upon the parents of white children, namely 'to mitigate the dominant culture's devaluing message'. 'Post-racialism' intensifies this task as, whilst no less pernicious, the threat of the devaluing message is rendered invisible. A positive racial identity can act as a buffer against the adversity racially minoritised students may face (Parham and Williams, 1993). As such, this becomes an integral component in Black mixed-race men's 'post-racial' resilience. To be clear, families of racially minoritized children have long since bolstered the resilience of their 
children. However, under the conditions of the 'post-racial', this task takes on a particular form.

For many of the men this support manifested as a relatively simple affirmation of their worth. Leon (UK) demonstrates this as he recalls, 'all my life my sister has told me that I'm beautiful, my Mum's told me that I'm beautiful'. Here Leon's white mother and white sister play an important role: as they affirm his Black mixed-race identity, they bolster his 'postracial' resilience. This is essential to Black mixed-race men's abilities to withstand the threat posed by the negative messages and images of Black mixed-race men that are so prevalent in white supremacist society. According to Leon, it is because of familial support, particularly from his white family (Twine, 2010), that he has 'never really seen anything wrong with myself'. Another UK participant, Alex, recalled the role his family played in cultivating a positive racial identity,

I think I've always been somewhat proud just cos of like the family that I've had around me, and not only like the family, just like extended family so that's on the Scottish side and also on the Nigerian side. I mean just being immersed in both the cultures... particularly on the Nigerian side.

As Lamont, Welburn and Fleming (2013) argue of African Americans, by cultivating and holding positive self, familial and community representations, racially minoritised groups are able to withstand the threat of racist representations, and speak back to the white gaze (Yancy, 2017). Again, whilst the threat remains, these negative representations are obscured and denied by the 'post-racial'. It is the exercising of 'post-racial' resilience, that enables Alex (UK) and Leon (UK) to combat racism. Taking the experiences of Leon and Alex side by side is particularly revealing. Whilst Alex was raised by his white mother and Black 
father, and had sustained contact with his Black family, Leon lived with his white mother and white sister, and had very limited contact with his Black father and extended Black family. Here, we can see how despite different family compositions, the families of Black mixed-race men can offer support in the cultivation of 'post-racial' resilience. As Twine (2010) has suggested, white parents are often able to develop the requisite racial literacy for raising Black mixed-race children. Whilst the ability of Black parents to support their Black mixedrace children in this regard has been considered somewhat axiomatic, the accounts in this article provide some empirical evidence.

In some instances, in both the UK and the US, parental input was born out of concern over how their sons identified racially. Carl (US) recalls a particular interaction with his father,

...my Dad is Black, full Black and we were riding in the car and I was telling him: 'Dad', I said, 'I'm mixed; I don't see myself as Black' and he was like, 'no listen son, in our society you're Black. You better accept right now that you are African American because you will always be viewed as African American'.

The intervention of Carl's father here is an attempt to avoid an incongruence between Carl's self-identification, and the way that he will be identified by others: an attempt to bolster Carl's resilience against the threat of racial mismatch. This is a threat that has been noted to be particularly prevalent for mixed-race populations (Campbell and Troyer, 2007). Undoubtedly influenced by the legacy of the one-drop rule, Carl's father reasons that Carl will be viewed by US society as Black, and therefore should 'accept' his interpellation and identity accordingly. Whilst perhaps threatening the erasure of Black mixed-race men's mixedness, the rationale behind Carl's intervention has pervaded thinking on Black mixedrace populations (Maximé, 1993; Tizard and Phoenix, 2002). Adherents of 'post-racial' logic 
would suggest that such an intervention is unnecessary. Whilst similar considerations have long since been a concern for Black mixed-race men's families, through its mystifying tendencies, the 'post-racial' turn bring with it further complications. 'Post-racial' logic is denied by Carl's father: he remains cognizant of the ways in which Black mixed-race men's bodies are distorted under the white gaze. Despite the 'post-racial' turn, Black mixed-race men's families cultivate resilience: this is 'post-racial' resilience. Trent, a UK participant, also recalled an incident in which potential racial mismatch led to a parental intervention. As he recalls having expressed a white racial identity in his early years, Trent continues (UK),

...my Mum quickly turned that around [laughs] and gave me a sit-down lesson... she probably was just shitting herself like oh crap, so we had the talk, and I think it was like one of the best talks ever and I think it's important, that talks like that start as young as possible, you know? Racial consciousness in Black young people is really important.

For Trent, this 'sit down lesson', a corrective to his apparent racial misidentification, plays a significant role in his development. As with Carl's father, this intervention involves eschewing the 'post-racial' logic that would suggest purely volitional identifications are possible. There is incongruity between Trent's self-identification as white, and the way he will be viewed by others. Trent's Black mother is able to identity this threat: so much so, that she was, according to Trent, 'shitting herself'. As Trent notes then, the talk becomes an important part in the cultivation of his 'post-racial' resilience. In effect, this is an intergenerational rejection of the 'post-racial'. For Trent, the development of racial consciousness, and the subsequent racial identity that is congruous with society, is 'really important'. A number of the informants in the study recalled having conversations with their parents as they developed nuanced identities that recognised Blackness and mixedness along 
intersecting lines of nationality, culture, ancestry, race and ethnicity. Trent (UK) also recalled another positive intervention his mother made. Here he reflects on his mother's decision to send him to a predominantly Black drama group,

I didn't know why she pushed me to do it but now I kind of obviously do but like, I was, I went to the local theatre group... it was predominantly Black kids doing theatre, and that was like an amazing thing cos it meant that once a week, subconsciously I was surrounded by Black people... it had mums that looked like my Mum... I didn't have to worry about other things, about my identity.

Trent argued that his mother's decision to expose him to other Black and Black mixed-race kids in such a deliberate way was a counterbalance against her decision, due to the school's league table placement, to send him to a predominantly white school. Recognising that race continues to be a determinant factor in friendships and peer groups, this drama school was a response to the potential threat of racial isolation (Caballero et al., 2008). It was, according to Trent, 'an amazing thing'. Trent's exposure to Blackness bolstered the 'post-racial' resilience he would need to withstand threats of isolation and the internalisation of pathological and stereotypical representations of Blackness. This intervention requires a rejection of 'postracial' logic and reflects the kind of work that the Black mixed-race men in this study reported their parents engaged in (Author A and co-author, 2016; Twine, 2010).

In some instances, the identity work of parents put them at odds with the school. Take the following account from Max (UK),

To be fair to my mum, she did try her best. She insisted that I had cornrows when I wanted them, cos that was a big part of being my colour and she put a big fight up at the school. 
The racial literacy of Max's mother is evident here as she recognises hair as an important component in Black and Black mixed-race identities (Mercer, 1994; Twine, 2010). Max recalls the role his mother plays in resisting the pressures of a white supremacist school system that sought to impose hegemonic whiteness through the policing of his hair. In this account, we can see how Max's mum bolsters his 'post-racial' resilience on at least two levels: by putting up a 'big fight', she supports him to resist the racialised disciplinary procedures of the school. Concomitantly, her intervention represents a refusing of the erasure of Black self-expression, Blackness, and Black hairstyles specifically. This intervention ensures Max is able to resist the metacommunication that a Black hairstyle, and thereby Blackness, is outside of the realms of acceptability. Whilst the preceding excerpts from Trent (UK) and Carl (US) talking about their Black parents, it is noteworthy here that Max's intervention comes from his mother who is white. Again, this troubles the axiom that racial literacy is the sole preserve of Black parents (Twine, 2010). Let us now turn to consider the role parents played as their sons encountered racism.

\section{Parents on Racism Experienced by Black Mixed-Race Men}

It was in terms of the threat of interpersonal racism that Black mixed-race men and their families most vehemently rejected 'post-racialism'. To do so, was seen to be of fundamental importance for well-being and for success in a potentially hostile schooling environment. Theo (UK) articulates this,

I don't think it matters what school you go to cos it's everywhere, know what I mean? So, if I had a child I'd send it to the best school possible; whether it's racist or not. Just hopefully bring them up to like be as strong as possible, know what I mean? Cos its everywhere, it is. 
What Theo articulates is a sense of an inevitability of interpersonal racism, that endures in 'post-racial' contexts. This episteme among Black families has been evidenced in existing research (Rhamie, 2007) and was a recurrent theme in the research. As Theo suggests, the challenge for the family becomes preparing their sons for experiences of interpersonal racism (Byfield, 2008; Miller and MacIntosh, 1999; Rhamie, 2007; Rokquemore and Laszloffy, 2005). Heather Dalmage (2000: 116) suggested it is best that families do 'not ignore race' but address 'race issues regularly'. Relatedly, Sanders (1997) found individuals with high levels of race consciousness were most likely to succeed in schooling. Under the conditions of the 'post-racial', these become increasingly important endeavours. The challenge for the family becomes cultivating the 'post-racial' resilience that their Black mixed-race son's will need as they encounter 'post-racial' interpersonal racisms. As Black and Black mixed-race families cultivate this 'post-racial' resilience, they draw upon 'an awareness of a shared tradition of resilience in the context of continued discrimination, which helps individuals to make sense of their experience' (Lamont et al, 2013: 144).

For Luke (UK) his familial support came as he was prepared for experiences of anti-Black racism (Twine, 2010); 'they told me all the words so like nigger, coon, Black bastard, or whatever; stuff like that'. It was because of this preparation, Luke continues, that 'it kind of got to a point where I didn't really care what it meant'. Luke's account reflected the accounts of Black mixed-race men in the UK and the US, and reaffirms Morley and Street's (2014: 53) findings that 'where families were affirmative and prepared to face these occurrences with their child, helping to develop their resilience, the insults and injuries are not reported as having had as serious and lasting effect.' Derrick (US) spoke about similarly pre-emptive support in terms of stereotypes, 
My Mum taught me growing up, like, here are the stereotypes; people are gonna think this about you but I know you're better than that and I know that you're gonna prove them wrong... I think it's good to understand the stereotypes around you so that you can know what people are gonna think about you before they even get to know you because it gives a chance for you to prove people wrong.

There are clear parallels between Luke's (UK) and Derrick's (US) accounts as we begin to get an insight into how the families of Black mixed-race men seek to cultivate 'post-racial' resilience in the face of threats of racism. Through his white mother's guidance, Derrick comes to identify pathological representations of Blackness as nothing more that fallacious stereotypes. Not only this, but as his mother affirms that he is 'better than that' and encourages him to 'prove people wrong' we begin to see parallels with the two previous subsections and thus how schooling, identity, and racism intersect.

Family support also came in the form of guidance on how Black mixed-race men should respond to instances of racism. Whilst this guidance varied considerably, it was apparent that in several cases parents were not afraid to advise their sons to tackle racism head on, often through physical violence. Take Shaun (UK) for instance,

When I was younger yeah, they definitely encouraged it like, to fight back. My Dad didn't really believe in like yeah, if someone calls you that he'd definitely encourage me to fight.

It is apparent here that Shaun's father is of the belief that to 'fight back' - to demonstrate an unwillingness to be subject to racist abuse - might enhance Shaun's 'post-racial' resilience. It is also conceivable that this guidance is particular to the intersection of race and gender for Black mixed-race men (Author, forthcoming). Thus, given the masculine culture that 
pervades schools (Pascoe, 2011), Shaun's dad sees masculine violence as a useful and commensurate response to his son's experience of racism. There was a widespread sense that school responses to racism were inadequate, and perhaps this made violence an appealing response (Author, 2016; Tikly et al., 2004). However, this was never absolute. Demonstrating the high levels of racial literacy in many Black mixed-race men's families, as Shaun (UK) grew older, his guidance adapted accordingly,

...now that I'm older they're like you need to be careful cos like police can get involved and things like that. So, you need to be smarter about it cos then it's affecting your life and career, do you know what I mean?

Again, rejecting 'post-racialism', the families of Black mixed-race men demonstrated an acute awareness of the threat posed by an institutionally racist police force that disproportionately targets Black and Black mixed-race men (Long, 2016). Indeed, as Shaun gets older the racialised spectres of arrest, incarceration and unemployment become very real threats against which Black mixed-race men must remain resilient (Yancy, 2017). This account shows not only that 'post-racial' resilience is cultivated reflexively, but also that important knowledge about racist institutions is transmitted inter-generationally. Conversations about policing were particularly prevalent in the US. Carl (US) recalls one such conversation with his mother,

She was like, 'Listen Carl, they're gonna see you differently'. If you get in trouble with white kids, you're gonna be in even more trouble and they're gonna single you out' and I was like, 'I know Mum, I know' And she just gave me like the warning signs of people. She understands the societal part of that; I'm understanding of that, but she just wanted to be sure, particularly with the cops and being in legal trouble. 
Just as in Shaun's (UK) case, Carl's (US) mother conveys an awareness of the institutional racism that permeates the policing and criminal justice system. As a Black mixed-race man, this is an important component in the cultivation of Carl's 'post-racial' resilience. Given the rhetoric around a school-to-prison pipeline for Black men in the US (Ferguson, 2001), and a similar spectre haunting Black men in the UK, it is unsurprising that parents felt that policing was an important topic to discuss with their sons. In terms of racism within the school, of which plenty was recalled, parental support was not only confined to advice and guidance. Where it was deemed necessary - and as in Max's earlier recollection of his Mother's intervention around school hair policy - parents were willing and able to intervene and confront the school. Take the following account from Leon (UK). After a teacher had facetiously told him that, 'in this country we put dots over our i's', he had relayed the incident to his mother. It was through conversations with his white mother that Leon came to recognise the racist message embedded in this remark. It was through his mother's racial literacy that Leon became better able to identify racial microaggressions and of course, in order to avoid internalising cultural deficit explanations, this is an essential component in his 'post-racial' resilience. Talking about his mother's reaction to the incident, Leon recalls,

My mum went mental, you know it was like year ten or something so I don't really remember it that detailed but I'm quite sure she called up the school and after that the teacher was nice to me; she didn't say anything again.

Here we see that as well as the conversation with Leon, his mother supports him with a direct intervention as she confronts the teacher and the school. This is an intervention that Leon values and one that had a positive impact on his schooling. Again, demonstrating the inseparability between schooling, identity and racism, there are clear parallels with the earlier 
discussed intervention of Jamal's mother who challenged a low grade, and Max's mother who challenged school hair policies.

\section{Conclusion}

In centring the accounts of Black mixed-race men, this article disrupts the too often pathological representations of the families of Black mixed-race men. Drawing upon Black mixed-race men's perspectives, this article demonstrates that rather than a site of instability, the family can offer an important site of support for Black mixed-race men as they move through a 'post-racial' white supremacist society generally, and 'post-racial' white supremacist schooling particularly. Reflecting an evolution of the forms of resilience that characterized pre-'post-racial' epochs, the article introduces the concept of 'post-racial' resilience in order to illuminate the important work of the family in enhancing the ability of Black mixed-race men to navigate terrain in which racism is a normalised, invisibilised, and inevitable presence. The article shows how 'post-racial' resilience can take on a multiplicity of forms for the families of Black mixed-race men and is important in terms of schooling, identity constitution, and dealing with racism.

In terms of schooling the article shows that contrary to popular beliefs, the families of Black mixed-race men place a high value on attainment and have high expectations for their sons. The high expectations of parents acted as a necessary combative to the gendered-racist low expectations that society generally, and school teachers particularly, hold of Black mixedrace men. Parents often adopted a race (and gender) conscious approach as they argued that societal racial inequity made it even more important for their Black mixed-race sons to gain school qualifications. Where necessary, parents were willing and able to challenge the school about the racially inequitable treatment of their sons. 
As has been shown, the parents of Black mixed-race men also played an important role in the identity constitution of their sons. As with parental advice on schooling, the Black mixedrace men in this study favoured a race conscious approach that recognised, and celebrated their racial identities. Parents can and do play an important role in countering the dominant pathological discourses on Black mixed-race men, in offering positive representations the parents and families enhanced the 'post-racial' resilience of Black mixed-race men. In some instances, parents worked hard to ensure that their sons held a self-conception that was in keeping with the way they would be viewed by others. Such guidance was deemed important in building the requisite 'post-racial' resilience to avoid a potentially problematic identity mismatch.

The third section of this article shows that the parents of Black mixed-race men tend to be proactive in countering and responding to experiences of racism. In some instances, this was achieved pre-emptively, as well as, where necessary, reactively. Parents and their sons rejected the 'post-racial' and assumed a sense of inevitability about racism and thus were able to respond to, and prepare for, the threat posed to their resilience. This was something that Black mixed-race men valued highly.

This article shows how the families of Black mixed-race men can and do enhance the "postracial' resilience of their sons on several levels. Moreover, in utilising data from two national contexts, the article shows how the 'post-racial' resilience enhancing potential of Black mixed-race men's families can be considered a transatlantic phenomenon. Whilst this article does not seek to shift the focus away from dismantling systemic white supremacy, it does counter popular discourse and show how the families of Black mixed-race men might be considered a site of strength, resistance, and 'post-racial' resilience. 


\section{Bibliography}

Alexander, C. E. 1996. The Art of Being Black. Oxford: Clarendon Press

Ali, S. 2003. Mixed-Race, Post-Race Oxford: Berg Publishers.

Andrews, K. 2013. Resisting Racism: Race, Inequality, and the Black Supplementary School Movement: Institute of Education Press.

Aspinall, P. J. 2003. "The Conceptualisation and Categorisation of Mixed Race/Ethnicity in Britain and North America: Identity Options and the Role of the State." International Journal of Intercultural Relations 27(3):269-96.

Aspinall, P. J. and M. Song. 2013. Mixed Race Identities. Basingstoke: Palgrave Macmillan.

Banks, N. 1995. "Children of black mixed parentage and their placement needs." Adoption \& Fostering 19.2: 19-24.

Banks, N. 1996. "Young single white mothers with black children in therapy." Clinical Child Psychology and Psychiatry 1.1 (1996): 19-28.

Beckles-Raymond, G. 2016. "Mixed Race Masquerades: Myths of Multiracial Harmony in Britain." Pp. 55-74 in Philosophy and the Mixed Race Experience, edited by T. F. Botts. London: Lexington.

Boushel, M. 1996. "Vulnerable Multiracial Families and Early Years Services: Concerns, Challenges and Opportunities." Children \& Society 10(4):305-16.

Byfield, C. 2008. Black Boys Can Make It: How They Overcome the Obstacles to University in the UK and USA. Stoke on Trent: Trentham Books Limited.

Caballero, C. 2004. "'Mixed Race Projects": Perceptions, Constructions and Implications of Mixed Race in the Uk and USA." University of Bristol.

Caballero, C., R. Edwards, and S. Puthussey. 2008. Parenting 'mixed' children: difference and belonging in mixed race and faith families, Joseph Rowntree Foundation, Available online from: https://www.jrf.org.uk/report/parenting-mixed-children-difference-andbelonging-mixed-race-and-faith-families

Campbell, M. E. and L. Troyer. 2007. "The Implications of Racial Misclassification by Observers." American Sociological Review 72(5):750-65. 
Christian, M. 2000. Multiracial Identity: An International Perspective, London: Macmillan

Clennon, O. D. 2014. "Making Education a Priority: An Overview." Pp. 1 in Alternative Education and Community Engagement: Making Education a Priority, edited by O. D. Clennon. Basigstoke: Palgrave Pivot.

Collins, P. H. 1994. "Shifting the Center: Race, Class, and Feminist Theorizing About Motherhood." Pp. 45-65 in Mothering: Ideology, Experience, and Agency, edited by Evelyn Nakano Glenn, Grace Chang and L. R. Forcey. London: Routledge.

Dalmage, H. 2000. Tripping on the Color Line: Black-white Multiracial Families in a Racially Divided World, London: Rutgers University Press

Daniel, G.R., Kina, L., Dariotis, W.M. and Fojas, C. 2014. Emerging Paradigms in Critical Mixed Race Studies. Journal of Critical Mixed Race Studies. 1 (1).

DeVerteuil, G. 2015. Resilience in the Post-Welfare Inner City: Voluntary Sector Geographies in London, Los Angeles and Sydney: Policy Press.

Ferguson, A. A. 2001. Bad Boys: Public Schools in the Making of Black Masculinity, Ann Arbor: University of Michigan Press.

Fletcher, M.E. 1930. Report on an Investigation into the Colour Problem in Liverpool and other Ports. Liverpool Association for the Welfare of Half-Caste Children.

Gillborn, D. 2001. "Racism, Policy and the (Mis) Education of Black Children." Educating our black children: new directions and radical approaches:13-27.

Gillborn, D. 2008. Racism and Education: Coincidence or Conspiracy? Abington: Routledge.

Gillborn, D. and G. Ladson-Billings. 2004. The Routledgefalmer Reader in Multicultural Education. London: Psychology Press.

Gilroy, P. 1993. Small Acts: Thoughts on the Politics of Black Cultures: Serpents Tail.

Goldberg, D. T. 2015. Are We All Postracial Yet? Cambridge: John Wiley \& Sons.

Greene, B. A. 1990. "What Has Gone Before: The Legacy of Racism and Sexism in the Lives of Black Mothers and Daughters." Women \& Therapy 9(1-2):207-30. 
Hall, P. A. and M. Lamont. 2013. Social Resilience in the Neoliberal Era: Cambridge University Press.

Hines, P. M. and N. Boyd-Franklin. 2005. "African American Families." Ethnicity and family therapy 3:87-100.

hooks, b. 2004. We Real Cool: Black Men and Masculinity. New York: Psychology Press.

Howard, T.C. and Flennaugh, T. 2011. Research concerns, cautions and considerations on Black males in a 'post- racial' society, Race Ethnicity and Education, 14 (1), pp.105120.

Hylton, K. 2012. "Talk the Talk, Walk the Walk: Defining Critical Race Theory in Research." Race Ethnicity and Education 15(1):23-41.

Jackson, C. L. 2001. African American Education: A Reference Handbook: ABC-CLIO.

Jackson, K. F., T. Wolven and K. Aguilera. 2013. "Mixed Resilience: A Study of Multiethnic Mexican American Stress and Coping in Arizona." Family Relations 62(1):212-25.

Lamont, M., J. S. Welburn and C. Fleming. 2013. "Responses to Discrimination and Social Resilience under Neo-Liberalism: The United States Compared." Pp. 129-57 in Social Resilience in the Neoliberal Age, edited by P. A. Hall and M. Lamont. Cambridge: Cambridge University Press.

Long, L. 2016. Still 'policing the crisis?': Black and mixed race experiences of policing in West Yorkshire. Leeds: PhD thesis submitted to the University of Leeds.

Malagon, M. C., L. Perez Huber and V. N Velez. 2009. "Our Experiences, Our Methods: Using Grounded Theory to Inform a Critical Race Theory Methodology." Seattle Journal of Social Justice 8:253.

Maximé, J. 1993. "The importance of racial identity for the psychological well-being of black children." ACPP Review and Newsletter 15.4: 173-179.

McNeil, D. 2010. Sex and Race in the Black Atlantic: Mulatto Devils and Multiracial Messiahs, London: Routledge

Mercer, K. 1994. Welcome to the Jungle. London: Routledge. 
Murad, N. L. 2005. The Politics of Mothering in a "Mixed" Family: An Autoethnographic Exploration, Identities, 12 (4), pp. 479-503

Miller, D. B. 1999. "Racial Socialization and Racial Identity: Can They Promote Resiliency for African American Adolescents?". Adolescence 34(135):493.

Miller, D. B and R. MacIntosh. 1999. "Promoting Resilience in Urban African American Adolescents: Racial Socialization and Identity as Protective Factors." Social work research 23(3):159-69.

Mills, C. W. 2007. White ignorance. In: Shannon Sullivan and Nancy Tuana eds. Race and epistemologies of ignorance. New York: State University of New York Press, pp.1138.

Mirza, H. S. and D. Reay. 2000. "Spaces and Places of Black Educational Desire: Rethinking Black Supplementary Schools as a New Social Movement." Sociology 34(3):521-44.

Morley, D. and C. Street. 2014. Mixed Experiences: Growing up Mixed Race-Mental Health and Well-Being. London: Jessica Kingsley Publishers.

Morning, A. 2012. Multiraciality and census classification in global perspective. In: Edwards, R., et al. eds. International Perspectives on Racial and Ethnic Mixedness and Mixing. Oxon: Routledge.

Owusu-Bempah, J. 1994. "Race, self-identity and social work." The British Journal of Social Work 24.2: 123-136.

Pascoe, C. J. 2011. Dude, You're a Fag: Masculinity and Sexuality in High School, Berkley, CA.: University of California Press

Parham, T. A. and P. T. Williams. 1993. "The Relationship of Demographic and Background Factors to Racial Identity Attitudes." Journal of Black Psychology 19(1):7-24.

Reddy, M. T. 1996. Crossing the Color Line: Race, Parenting, and Culture: Rutgers University Press.

Rhamie, J. and S. Hallam. 2002. "An Investigation into African-Caribbean Academic Success in the UK." Race, Ethnicity and Education, 5(2):151-70. 
Rhamie, J. 2007. Eagles Who Soar: How Black Learners Find the Path to Success. Stoke on Trent: Trentham Books.

Rockquemore, K. and Laszloffy, T. A. 2005. Raising Biracial Children, AltaMira Press.

Sanders, M. G. 1997. "Overcoming Obstacles: Academic Achievement as a Response to Racism and Discrimination." Journal of Negro Education:83-93.

Small, S. 2001. "Colour, culture and class: interrogating interracial marriage and people of mixed racial descent in the USA." IN D. Parker and M. Song (eds.) Rethinking 'Mixed Race', London: Pluto Press 117-33.

Song, M. 2015. "Does a Recognition of Mixed Race Move Us Towards Post-Race? ." Pp. 7493 in Theories of Race and Ethnicity, edited by K. Murji and J. Solomos. Cambridge: Cambridge University Press.

Staples, R. 1999. The Black Family: Essays and Studies: Cengage Learning.

Stonequist, E.V. 1937. The marginal man: a study in personality and culture conflict. New York.

Tate, S. A. 2015. "Performativity and 'Raced' Bodies." Pp. 180-98 in Theories of Race and Ethnicity, edited by K. Murji and J. Solomos. Cambridge: Cambridge University Press.

Tate, S. A. 2005. Black Skins, Black Masks: Hybridity. Dialogism, Performativity. Aldershot Ashgate Publishing.

Tikly, L., C. Caballero, J. Haynes and J. Hill. 2004. Understanding the Educational Needs of Mixed Heritage Pupils: DfES London.

Tizard, B. and A. Phoenix. 2002. Black, White or Mixed Race?: Race and Racism in the Lives of Young People of Mixed Parentage. London: Psychology Press.

Tutwiler, S. W. 2016. Mixed-Race Youth and Schooling: The Fifth Minority. Abingdon: Routledge.

Twine, F. W. 2004. A white side of black Britain: The concept of racial literacy, Ethnic and Racial Studies, 27 (2) 
Twine, F. W. 2010. A White Side of Black Britain: Interracial Intimacy and Racial Literacy: Duke University Press.

Ward, J. V. 1996. Raising Resisters: The Role of Truth Telling in the Psychological Development of African American Girls, In Ross, B. and Way N. (eds.) 1996. Urban Girls: Resisting Stereotypes, Creating Identities, New York, N.Y.: New York University Press

Warikoo, N. K. 2011. Balancing acts: Youth culture in the global city. Berkley: University of California Press.

Warmington, P. 2014. Black British Intellectuals and Education: Multiculturalism's Hidden History. London: Routledge.

Williams, D. 2011. Mixed Matters: Mixed-Race Pupils Discuss School and Identity. London: Troubador Publishing Ltd.

Wilson, A. 1987. Mixed Race Children: A Study of Identity, London: Allen and Unwin

Wise, T. 2013. Colorblind: The rise of post-racial politics and the retreat from racial equity. San Francisco: City Lights Books.

Yan, W. 1999. "Successful African American Students: The Role of Parental Involvement." Journal of Negro Education, 5-22.

Yancy, G. 2017. Black Bodies, White Gazes: The Continuing Significance of Race: Second Edition. Lanham: Rowman \& Littlefield Publishers. 